UDK: $336.761 / .763 ; 336.581: 502.14$

CERIF: S144

ТИП РАДА: ИЗВОРНИ НАУЧНИ РАД

DOI: $10.5937 / \mathrm{PiP} 2002137 \mathrm{~S}$

\title{
др Ранко СОВИљ
}

научни сарадник на Институту друштвених наука у Београду

\section{ТРЖИШТЕ ЗЕЛЕНИХ ХАРТИЈА ОД ВРЕДНОСТИ - СТАҢЕ И ПЕРСПЕКТИВЕ ${ }^{1}$}

\begin{abstract}
Сажетак
Зелено финансиране ирреgсйављь области финансија која се йозиционира између финансијской сектиора, оярживоі економскоі развоја и за-

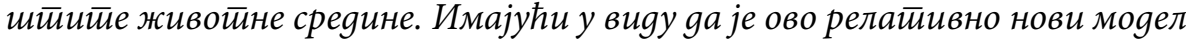
финансирағь, који је још увек у йовоју, йреgмети раgа је анализа ииренуйноі сииана зелених финансија, ирре свеїа зелених харйија оg вреgностии.

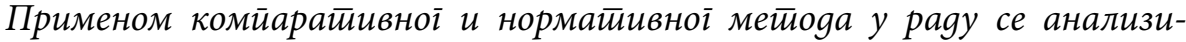

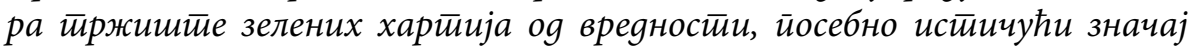

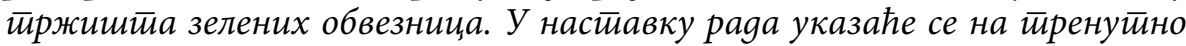

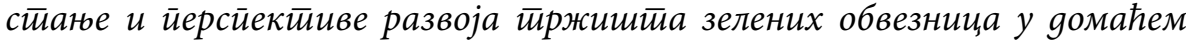

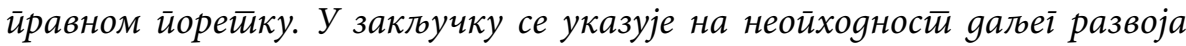
йржитйа зелених обвезница и усмераваюа иослована финансијских инстиитиција у ирравиу креираға нових зелених йроизвоgа и услуїа.
\end{abstract}

Кључне речи: Зелене финансије. - Тржишие харитија оg вреgносиии. Зелене харииије оg вредностии. - Зелене обвезнице. - Кай обвезнице. - Муницийалне обвезнице.

* Електронска адреса аутора: soviljpeca@gmail.com; rsovilj@idn.org.rs.

1 Рад је написан у оквиру Програма истраживања Института друштвених наука за 2020. годину који подржава Министарство просвете, науке и технолошког развоја. 


\section{І Увод}

Зелено финансирање представља област финансија која се првенствено односи на област заштите животне средине пласирањем нових финансијских производа и услуга. Све израженија заинтересованост инвеститора допринела је развоју тржишта зелених хартија од вредности. Зелене хартије од вредности представљају финансијски механизам који је указао на то да тржишта капитала могу бити извор финансирања пројеката којима се решавају проблеми климатских промена. Основни циљ је пружање инвеститорима нових производа и услуга на тржишту капитала који задовољавају њихову потражњу и којима је обухваћен ризик улагања. ${ }^{2}$ Истовремено, инвестирањем у зелене хартије од вредности, пре свега зелене обвезнице, прикупљају се средства којима се финансирају пројекти који имају за циљ заштиту животне средине, смањење емисије штетних гасова и истовремено се омогућава земљама да се прилагоде утицајима климатских промена.

Узимајући у обзир да је посреди релативно нова и недовољно истражена област финансирања, полазна основа за разматрање предметне теме јесте указивање на значај емисије зелених хартија од вредности која омогућава прикупљање средстава којима се финансирају пројекти који доприносе очувању животне средине. Полазећи од претпоставке да су зелене хартије од вредности драгоцено средство у борби против климатских промена и да би требало подстаћи развој одрживог тржишта зелених обвезница, у раду се критички сагледава регулаторни оквир примењив на зелене обвезнице. Најпре ћемо у раду одредити појам зелених финансија. У наставку рада дефинисаћемо шта су зелене обвезнице, указати на интересе емитената и инвеститора и дати преглед тренутног тржишта зелених обвезница. С обзиром на то да је ово питање недовољно обрађено на нашим просторима, пре свега са правног становишта, на крају рада указаћемо на регулаторни оквир тржишта зелених хартија од вредности у Републици Србији, као и на предности и могућности овог начина финансирања који би допринео свеукупном развоју домаће привреде.

\section{II Појам и одређење зелених финансија}

У свету не постоји општеприхваћена дефиниција која прецизно одређује појам зелених финансија. Штавише, не употребљава се само

2 Драгица Стојановић, „Зелене финансије - тренд који прати концепт одрживог економског развоја“, 9. Међунаровни симйозијум о уйрављьаюу иррировним ресурсима (ур. Драган Михајловић, Бојан Ђорђевић), Факултет за менаџмент Мегатренд Универзитета у Зајечару, Београд, 2019, 349. 
појам „зелене финансије“, већ се користе и други слични термини указујући на све већи значај концепта зелених финансија. У том контексту, термин „зелене финансије“ у корелацији са зеленим (одрживим) растом може се објаснити помоћу концепта одрживих финансија, финансирања животне средине, финансирања смањења емисије штетних гасова и климатских промена. ${ }^{3}$

Концепт зелених финансија претпоставља имплементирање нових метода и технологија које имају за циљ креирање нових (зелених) финансијских производа и услуга које превасходно узимају у обзир заштиту животне средине, енергетску ефикасност, смањење емисије штетних гасова, рециклажу и очување биодиверзитета. Стога, зелене финансије се позиционирају у пресеку између финансијског сектора, заштите животне средине и одрживог економског развоја. 4

„Зелени“ тренд, који је последњих година изузетно актуелан у свету, настао је из потребе да максимизирање профита не буде једини (приоритетни) циљ, већ да се паралелно са стицањем профита поведе рачуна о очувању животне средине и друштвено одговорном пословању финансијских институција. С тим у вези, политика зелених финансија подразумева преоријентисање са профита као примарног, ако не и јединог циља предузетих активности финансијских институција, ка циљевима који инкорпорирају одрживи развој, заштиту животне средине и друштвено одговорно пословање уз неизбежно остварење профита. Данас је изражен тренд глобалног финансирања одрживог развоја праћен експанзијом приватних токова капитала. Као глобални тренд, концепт зелених финансија промовисан је од стране међународних организација попут Уједињених нација, Светске банке, Светске трговинске организације и Г20. Улажу се велики напори у политици заштите животне средине на међународном нивоу у погледу увођења еколошких такси, еколошких надокнада и сл. ${ }^{5}$

Насупрот конвенционалним (традиционалним) финансијским инструментима, зелени финансијски инструменти истичу корист од еколошке заштите и усмерени су ка индустрији заштите животне средине. Сходно томе, концепт зелених финансија претпоставља низ регу-

3 Hee Jin Noh, Financial Strategy to Accelerate Green Growth, ADBI Working Paper Series, Nr. 866/2018, доступно на адреси: https://www.adb.org/sites/default/files/publica tion/452656/adbi-wp866.pdf, 5. 4. 2020, 3.

4 Слободан С. Ракић, Петар Д. Митић, Неда В. Распоповић, „Примена концепта „зеленог“ у финансијама и банкарству“, Пословна економија, бр. 1/2012, 168.

5 Драгица Стојановић, Гордана Ђукић, „Зелено финансирање на међународном нивоу - поређење Србије и Сингапура“, 9. Међународни симйозијум о уйрављьюьу йриродним ресурсима (ур. Драган Михајловић, Бојан Ђорђевић), Факултет за менаџмент Мегатренд Универзитета у Зајечару, Београд, 2019, 327. 
латорних мера и политика, институционалних аранжмана, као и адекватну финансијску инфраструктуру која путем кредитирања, сакупљања приватног капитала, емисијом зелених обвезница, емисијом других финансијских инструмената и трговином на секундарном тржишту капитала прикупља средства која се усмеравају ка еколошки прихватљивим пројектима и активностима. ${ }^{6}$

Тренд „озелењавања“ финансијског сектора све више узима маха, како у развијеним тржишним економијама, тако и у земљама у развоју. Кључни актери који иницирају развој зеленог финансирања су банке, институционални инвеститори, инвестициони фондови, осигуравајућа друштва, међународне финансијске институције, централне емисионе банке, као и национални регулатори на тржишту капитала. ${ }^{7}$ Данас се многобројна финансијска средства, попут зелених кредитних линија, зелених обвезница и других зелених хартија од вредности, користе као инструменти зелених финансија, о чему ће бити више речи у наставку рада.

\section{III Тржиште зелених хартија од вредности - регулаторни оквир}

Као што је претходно истакнуто, зелене хартије од вредности подржавају финансирање активности и пројеката који имају за циљ очување животне средине. Управо у томе се огледа њихова специфичност у односу на традиционалне хартије од вредности, с обзиром на то да је емитент зелених хартија од вредности дужан да прикупљена средства усмери на финансирање пројеката који имају позитиван утицај на заштиту животне средине. То недвосмислено указује на обавезу емитента да се прикупљена средства користе за финансирање зелених пројеката или пословних активности. Како истиче Heidi Vella, прикупљена средства могу се усмерити на: енергетску ефикасност (укључујући изградњу енергетски ефикасних зграда); одрживо управљање отпадом; одрживо коришћење земљишта (одржива пољопривреда и шумарство); одрживо управљање водама; очување биодиверзитета; чист транспорт и прилагођавање климатским променама. 8 Највеће учешће на тржишту зелених хартија од вредности има зелена обвезница, те ће се наведени термин употребљавати у наставку рада.

6 Yao Wang, Qiang Zhi, „The Role of Green Finance in Environmental Protection: Two Aspects of Market Mechanism and Policies“, Energy Procedia, Nr. 104/2016, 311-312.

7 Д. Стојановић, 350.

8 Д. Стојановић, 353. Цитирано према: Heidi Vella, „Global Green Bond Partnership: reinvigorating energy investment“", доступно на адреси: http://www.power-technology. com/features/global-green-bond-partnership/, 3. 4. 2020, 1. 
Развој тржишта зелених обвезница текао је узлазном путањом иако није постојао регулаторни оквир за зелене обвезнице на међународном нивоу. Прву серију зелених обвезница емитовала је Европска инвестициона банка (European Investment Bank - EIB) током 2007. године. Све до 2013. године тржиштем зелених обвезница доминирале су међународне агенције и међународне развојне банке попут Светске банке, Афричке развојне банке и Међународне финансијске корпорације (International Finance Corporation - IFC). Као резултат повећане ликвидности у сектору, у развијеним земљама су током 2013. године велике мултинационалне компаније, попут Apple, Engie и Toyote, емитовале зелене обвезнице. У датом периоду, велику већину емисија зелених обвезница спровеле су банке с циљем прикупљања капитала који би био усмерен на финансирање зелених пројеката. ${ }^{9}$ Даљем развоју тржишта зелених обвезница допринело је увођење Међународне асоцијације тржишта капитала (International Capital Market Association - ICMA) јануара 2014. године и усвајање Принципа зелених обвезница.

Током 2015. године долази до експанзије тржишта зелених обвезница. Оквирна конвенција Уједињених нација о климатским променама подржала је Климатски споразум из Париза чији је циљ јачање глобалног одговора на претњу климатским променама у контексту одрживог развоја и смањења стопе сиромаштва. ${ }^{10} \mathrm{C}$ тим у вези, државе чланице обавезују се да обезбеде да се јавни и приватни финансијски токови користе сходно препорученим стандардима о одрживом климатском развоју. То је допринело даљем развоју тржишта зелених обвезница; кинески емитенти су ушли на тржиште, почело се са емитовањем државних и муниципалних обвезница. ${ }^{11}$ Већина зелених обвезница котирана је на берзама широм света: на Лондонској ефектној берзи, на берзама у Луксембургу, Стокхолму, Ослу и Мексику. ${ }^{12}$ Према подацима

9 Alex Ross, Green Bonds: Securities Regulation Towards a Low-carbon Economy, Victoria University of Wellington Faculty of Law, 2018, 12.

10 Оквирна конвенција Уједињених нација о климатским променама (United Nations Framework Convention on Climate Change), 1992, доступно на адреси: https://unfccc. int/files/essential_background/background_publications_htmlpdf/application/pdf/conveng. $p d f, 6.4$. 2020; Извештај са конференције у Паризу (Report of the Conference of the Paris on its twenty-first session), Paris, 30 November to 13 December 2015, доступно на адреси: https://unfccc.int/resource/docs/2015/cop21/eng/10a01.pdf, 6. 4. 2020, annex 1, чл. 2.

11 Број држава које су емитовале зелене обвезнице порастао је на 37, док је Француска постала лидер на тржишту зелених обвезница. Зелене обвезнице које су емитовале Француска, САД и Кина чине чак 56\% тржишта зелених обвезница. Упркос томе, тржиште зелених обвезница је и даље мало у поређењу са глобалним тржиштем традиционалних обвезница. Д. Стојановић, 354.

12 A. Ross, 13. 
Организације за економску сарадњу и развој (Organization for Economic Co-operation and Development - OECD), приходи прикупљени од емисије зелених обвезница у 2015. години распоређени су на следећи начин: $46 \%$ прикупљених средстава усмерено је ка обновљивим изворима енергије; 20\% на пројекте енергетске ефикасности; 13\% на пројекте усмерене на смањење емисије штетних гасова; 9\% на пројекте управљања водама; 6\% на управљање отпадом; 4\% на прилагођавање климатским променама; $2 \%$ на одрживо коришћење земљишта (пољопривреда и шумарство). ${ }^{13}$

Многи инвеститори на тржишту зелених обвезница су потписници Принципа одговорног финансирања или чланови Групе институционалних инвеститора за климатске промене. У међувремену, зелене обвезнице постале су главни финансијски инструмент на тржишту зелених хартија од вредности. Иако се тржиште зелених обвезница убрзано развило у односу на 2007. годину, у 2016. години чинило је само 1,6\% светског тржишта обвезница. Испоставило се да годишње емисије зелених обвезница нису довољне да задовоље потражњу инвеститора, те су многе емисије зелених обвезница претплаћене. Управо висока емисиона цена зелених обвезница, као и податак да су поједини инвеститори куповали и држали у свом портфељу зелене обвезнице, резултирало је незадовољством осталих институционалних инвеститора и ниском ликвидношћу на тржишту зелених обвезница. ${ }^{14}$

Упркос експанзивном расту тржишта зелених хартија од вредности претходних година и даље не постоје јединствена правила којима се регулише њихова емисија и промет на међународном тржишту капитала. У недостатку регулаторног оквира, берзе и агенције за кредитни рејтинг имале су пресудну улогу у регулисању трговине зелених хартија од вредности и обезбеђивању несметаног пословања међународног тржишта капитала. ${ }^{15}$ Регулаторни оквири у већини развијених земаља, укључујући државе Европске уније и САД, не праве дистинкцију између зелених и традиционалних обвезница. Као резултат тога, захтеви који се односе на упис хартија од вредности, објављивање понуде, проспекта и укључивање на тржиште, важе за све врсте дужничких хартија од вредности. ${ }^{16}$ То нам имплицитно указује на то да се правила која се односе на традиционалне обвезнице примењују и на зелене обвезнице. С друге стране, Кина и Индија су једине земље које су усвојиле посебне прописе којима се регулише емисија зелених обвезница и њихово укључивање на

13 Organization for Economic Cooperation and Development, Green Finance and Investment: Mobilising Bond Markets for a Low-Carbon Transition, OECD Publishing, 2017, 24.

14 A. Ross, 13.

15 Ibid., 14.

16 Ibid., 15. 
секундарно тржиште. У недостатку јединствених међународних и националних прописа приступило се регулисању правног оквира зелених обвезница од стране берзи, осигуравајућих друштава и кредитних рејтинг агенција. Међутим, прописи које су усвојиле наведене институције нису правно обавезујући, те их емитент може добровољно прихватити приликом емисије зелених обвезница. ${ }^{17}$

У циљу ублажавања забринутости услед раширености „зеленог прања (greenwashing)“18 и превара инвеститора на тржишту зелених хартија од вредности, креиране су мере саморегулације, укључујући смернице, препоруке, водиче и стандарде добре праксе. На глобалном нивоу, најраспрострањенији су Принципи зелених обвезница и Стандарди за климатске обвезнице. Принципе зелених обвезница (Green Bond Principles - GBP) донела је Међународна асоцијација за тржиште капитала (финансијска институција фокусирана на регулаторна и тржишна питања) у циљу повећања транспарентности, објављивања информација и извештавања на тржишту зелених обвезница. Принципи представљају скуп смерница којима се уређују поступци на добровољној основи и осликавају најбољу праксу зелених обвезница. ${ }^{19}$ Стандарде за климатске обвезнице (Climate Bonds Standards - CBS) креирала је Иницијатива за климатске обвезнице (Climate Bonds Initiative - $C B I)$ у циљу мобилизације капитала у борби против климатских промена. 20

\section{1. Појам и обележја зелених обвезница}

Зелена обвезница (Green Bond) је интегрална компонента зелених финансија и један од најперспективнијих начина помоћу којег се капитал приватног сектора може активирати у борби против климатских промена. Термин зелена обвезница спомиње се 1949. године и користи се у индустрији за прераду чистог облика бентонита названог „Federal Green Bond“ за који се сматрало да је саставни део процеса топљења.

17 Ibid., 19.

18 Greenwashing представља концепт у коме организације покушавају да помоћу „зелених“ PR и маркетинг активности промовишу своју организацију као еколошки свесну и друштвено одговорну, а да при том она то није. Слободан Ракић, Петар Митић, Green Banking - Green Financial Products with Special Emphasis on Retail Banking Products, Vydavatel'stvo Prešovskej University, Presov, 2012, 56.

19 Принципи зелених обвезница Међународне асоцијације за тржиште капитала (International Capital Markets Association, Green Bond Principles - Voluntary Process Guidelines for Issuing Green Bonds), ICMA publishing, June 2018, 2.

20 Стандарди за климатске обвезнице Иницијативе за климатске обвезнице, (Climate Bonds Initiative, Climate Bonds Standards), Version 2.1, Climate Bonds Initiative Publishing, 2017. 
Финансијски сектор присвојио је термин зелена обвезница 2007. године за описивање хартије од вредности са фиксним дохотком чији су приходи од емисије усмерени у еколошки прихватљиве пројекте и активности. Као што смо већ навели, иако их првобитно емитују међународне мултилатералне институције, корпоративне и државне обвезнице које су се појавиле у наредном периоду подстакле су огроман раст у финансијском сектору - годишња емисија зелених обвезница порасла је са четири милијарде долара у 2010. години на више од 150 милијарди долара у 2017. години. ${ }^{21}$

Дефиниција зелене обвезнице, која је начелно општеприхваћена, одређује зелену обвезницу као традиционалну (конвенционалну) обвезницу чији су приходи од емисије намењени пројектима који: 1) помажу заједници да се прилагоди ефектима климатских промена и/или 2) генеришу позитивне еколошке користи. Наведена дефиниција недвосмислено укључује обвезнице чији приходи ће ублажити последице климатских промена. Такође, екстензивним тумачењем ове дефиниције закључујемо да она обухвата обвезнице чији ће приходи финансирати активности и пројекте заштите животне средине који нису блиско повезани са климатским променама, попут унапређења биодиверзитета и третмана воде. С друге стране, Програм Уједињених нација за развој (United Nations Development Programme - UNDP) одређује зелене обвезнице као конвенционалне обвезнице чији ће се приходи уложити у пројекте који доносе корист у очувању животне средине. Заправо, истиче се да се једина разлика између зелених обвезница и традиционалних обвезница огледа у томе што се приходи од емисије инвестирају у пројекте који доприносе очувању животне средине. ${ }^{22}$ Дефиниција УНДП не препознаје прилагођавање као интегрални део постигнутог међународног договора о климатским променама. Када се схвати важност ове примедбе, сасвим је оправдано дефиницијом зелених обвезница обухватити и оне обвезнице чији приходи ће омогућити корист међународној заједници у борби против климатских промена. ${ }^{23}$ Ову дефиницију подржава и Иницијатива за климатске обвезнице (Climate Bonds Initiative - CBI), као водећи лидер у примени најбоље праксе зелених обвезница, наводећи да се приходима од зелених обвезница могу финансирати пројекти одрживог климатског развоја. Препорука свим инвеститорима, државама и другим учесницима је да инвестирају у пројекте смањења емисије штетних гасова и отклањању последица кли-

\footnotetext{
21 A. Ross, 6.

22 United Nations Development Programme, „Green Bonds“ - UNDP „Green Bonds“, UNDP Publishing, 2016, доступно на адреси: https://www.undp.org/content/dam/sdfi nance/doc/green-bonds, 6. 4. 2020, 1.
}

23 A. Ross, 8. 
матских промена. ${ }^{24}$ На том становишту је и Светска банка која подржава пројекте одрживог развоја. Зелени пројекти Светске банке усмерени су на смањење сиромаштва и унапређење локалних привреда. Нарочита пажња поклања се последицама климатских промена које непосредно погађају земље у развоју. ${ }^{25}$

Флексибилност структурирања обвезница резултирала је настанком неколико врста зелених обвезница. Иницијатива за климатске обвезнице идентификовала је четири врсте обвезница: зелена употреба прихода од обвезница, зелена нерегресна обвезница, зелена пројектна обвезница и зелена секјуритизована обвезница. ${ }^{26}$ Најновија врста зелених обвезница је green sukuk, односно зелена обвезница која је уподобљена стандардима исламских финансија. ${ }^{27} \mathrm{C}$ обзиром на то да су карактеристике које их међусобно разликују искључиво финансијске природе, у раду су све зелене обвезнице третиране истоветно.

\section{2. Остале врсте зелених хартија од вредности}

Осим зелених обвезница постоји велики број зелених хартија од вредности креираних за посебне намене. Пример таквих обвезница је шумска обвезница (Forest Bond) емитована у циљу финансирања реконструкције Панамског канала како би се уклонили и ублажили проблеми транспорта каналом. У оквиру пројекта Beyond Timber извршена је емисија обвезница са роком доспелости од 25 година. Инвеститори у ове обвезнице су стејкхолдери који иначе користе овај водени пут. ${ }^{28}$

24 Стандарди за климатске обвезнице Иницијативе за климатске обвезнице, 2.

25 Прва емисија зелених обвезница Светске банке из новембра 2010. године дистрибуирана је само у Сједињеним Америчким Државама. Циљ емисије био је прикупљање средстава од инвеститора који очекују фиксни повраћај на своја улагања. Светска банка је у виду зајмова прикупљеним средствима финансирала пројекте усмерене на ублажавање климатских промена. Вид. Мила Јанчетовић, Рaдица Јовановић, Јана Цвијић, „Стратегија комуникације банака и осигуравајућих компанија за одрживи развој“, Моћ комуникације 2012 (ур. Зорка Грандов, Марко Лакета, Санел Јакуповић), Паневропски универзитет Апеирон у Бањој Луци, Бања Лука, 2012, 61.

26 UNDP „Green Bonds“, 1.

27 United Nations Development Programme, Green Bond/Green Sukuk Service Lines, UNDP Indonesia, 2017, доступно на адреси: https://www.undp.org/content/dam/undp/library/ corporate/Financial\%20Institutions/UNDP_IFIs_Green\%20BondGreen\%20Sukuk\%20 Service\%20Lines_.pdf, 6. 4. 2020, 10.

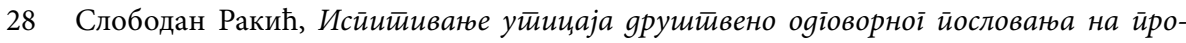
фитиабилности банака у Евройској унији, докторска дисертација, Факултет пословне економије Универзитета Едуконс у Сремској Каменици, Сремска Каменица, 2016, 102. 
Добар пример иновативног приступа тржишту капитала су „кат обвезнице“ (CAT) или обвезнице катастрофе, креиране због климатских промена. У питању је релативно нов финансијски инструмент потенцијално високог приноса и високог ризика који је углавном повезан са осигурањем. Заправо, обвезнице катастрофе представљају дужничке хартије од вредности које су прилагођене реосигурању у циљу преношења ризика услед реализације катастрофалних штета изазваних климатским променама. Циљ емисије кат обвезница јесте прикупљање средстава у случају наступања природних катастрофа попут земљотреса, урагана, олујних ветрова, цунамија и сл. Најчешћи емитенти обвезница катастрофе су осигуравајућа друштва, али и државне агенције и велике инвестиционе компаније попут Merrill Lynch. ${ }^{29}$ Кат обвезнице емитоване су у процесу секјуритизације катастрофалних ризика највећих финансијских институција попут BNP Paribas, Goldman Sachs, Lehman Brothers. ${ }^{30}$ Наиме, кат обвезнице представљају резултат поступка секјуритизације којим се ризик осигурања преноси у ликвидни финансијски инструмент којим се тргује на секундарном тржишту капитала. Кат обвезнице омогућују спонзору (осигуравајућа и реосигуравајућа друштва, компаније) да у моменту наступања предвиђеног катастрофалног догађаја не изврши своју обавезу. У том случају, уколико се реализује осигурани случај, инвеститори који су уложили у ове обвезнице могу изгубити припадајућу камату и главницу. Међутим, ако се унапред одређени штетни догађај, по основу кога је обвезница емитована, не догоди у том случају ће инвеститори осим главнице добити и припадајућу камату која је истоветна камати на неризична улагања увећаној за премију за преузети ризик. На основу изложеног, закључује се да кат обвезнице имају обележја тзв. junk bonds, односно високоризичних обвезница. ${ }^{31}$

Прве кат обвезнице емитоване су 1992. године након урагана Ендрју, да би потом развој ових обвезница узео маха 1997. године. Додатном развоју кат обвезница допринели су измењени модели процењивања ризика, као и строжи захтеви регулаторних органа и кредитних рејтинг агенција у погледу расположивог капитала. С обзиром на то да су тржишту осигурања недостајала средства за прихватање ризика, а да су тржишту капитала недостајале хартије од вредности којима би се унапредиле перформансе инвестиционих портфеља, до-

29 Марија Тасић, Правни аспекти издавања и конверзије заменљивих обвезница, доступно на адреси: $h t t p: / / w w w . t a s i c l a w . c o m / f a j l o v i / p r o c e d u r a \_z a \_i z d a v a n j e \_z a m e n l j i v i h \_$ obveznica.pdf, 10. 4. 2020, 3.

30 С. Ракић, 102.

31 Владимир Његомир, „Улога тржишта капитала у управљању ризиком осигурања“, Иняустирија, бр. 4/2008, 103. 
лази до убрзаног развоја кат обвезница. ${ }^{32}$ Као предност кат обвезница истиче се изузеће од опорезивања прихода ових обвезница, што би додатно поспешило развој тржишта кат обвезница. Тиме се омогућава осигуравајућим друштвима приступ средствима на тржишту капитала, што консеквентно доводи до повећаних финансијских могућности осигуравача у пружању осигуравајућих покрића за ризике изазване природним непогодама. ${ }^{33}$ Најчешћи инвеститори у кат обвезнице су институционални инвеститори, пензиони фондови и хеџ фондови.

Поједини аутори наводе да је тржиште кат обвезница изузетно атрактивно и перспективно за инвеститоре из разлога што кат обвезница није у корелацији са остатком финансијског тржишта, односно прецизније, са кретањима на тржишту власничких вредносних папира, кредитним ризиком и ризиком каматне стопе. У међувремену, осигуравајућа друштва раде на креирању нових модела кат обвезница којима би се покрили нови типови ризика, попут cyber напада и ризика од тероризма. ${ }^{34}$

\section{Tржиште зелених хартија од вредности у Србији - стање и перспективе}

Закон о тржишту капитала не препознаје зелене хартије од вредности као именоване хартије. Међутим, то не значи да је емисија и трговина ових хартија од вредности забрањена. Наиме, закон даје право на стицање и продају таквих преносивих хартија од вредности по основу којих се може обављати плаћање у новцу, а чији се износ утврђује на основу преносиве хартије од вредности, валуте, каматне стопе, приноca, индекса или других одредивих вредности. ${ }^{35} \mathrm{C}$ обзиром на то да закон није усвојио принцип numerus clausus, издаваоцима је допуштено да емитују, поред већ постојећих именованих хартија од вредности, и нове хартије од вредности које нису прописима именоване и уређене. У том случају, да би се одобрио поступак емисије нових хартија од вредности, емитент је обавезан да прибави претходну сагласност органа званичног надзора на тржишту капитала - Комисије за хартије од вредности. ${ }^{36}$

32 Владимир Његомир, „Управљање ризиком у осигурању емисијом обвезница за катастрофалне штете“, Економска мисао, бр. 3-4/2006, 186.

33 В. Његомир (2006), 187.

34 Емира Козаревић, Харис Мујић, „Финансирање катастрофалних ризика САТ обвезницама“, Банке и бизнис, јул/август 2019, 59.

35 Закон о тржишту капитала, Службени іласник РС, бр. 31/2011, 112/2015, 108/2016 и 9/2020, чл. 2 ст. 2 тач. 3.

36 Небојша Јовановић, Берзанско йраво, Правни факултет Универзитета у Београду, Београд, 2009, 425. 
Комисија ће издати сагласност емитенту за емисију нове врсте хартије од вредности када констатује да су испуњени законом прописани услови у погледу постојања издаваоца, законитости његовог пословања, преносивости хартија, садржине хартија, уједначености и масовности, као и обавештености и заштићености инвеститора. С обзиром на то да на тржишту зелених хартија од вредности доминирају зелене обвезнице које представљају дужничке хартије од вредности, ${ }^{37}$ емитент може одлуком о емисији самостално да уреди садржину обавезе према имаоцима (инвеститорима) и да им одреди име. ${ }^{38}$

Да би се у Републици Србији успешно спровела емисија зелених хартија од вредности, неопходни су стабилни и значајни извори финансијских средстава који се једино могу обезбедити емисијом зелених муниципалних обвезница. Међутим, тренутна средства прикупљена из буџета јединица локалних самоуправа, донација, помоћи међународних организација и банака, као и средстава Фонда за заштиту животне средине, нису довољна за реализацију зелених пројеката. На основу извештаја Зеленог фонда, основаног при Министарству за заштиту животне средине 2016. године, у Србији се издваја 10 пута мање буџетских средстава наспрам Европске уније. ${ }^{39}$ у циљу реализације зелених активности и пројеката, неопходно је издвајање већих средстава на нивоу јединица локалне самоуправе истовремено са унапређењем ефикасности рада органа јединица локалних самоуправа, те контролисањем трошења буџетских средстава за заштиту животне средине и обновљивих извора енергије.

Тржиште муниципалних обвезница у Србији је релативно скромно и неразвијено, и тренутно се налази у почетној фази. До сада су само четири локалне самоуправе (градови Нови Сад, Панчево, Шабац и општина Стара Пазова) спровеле емисије муниципалних обвезница чија су средства намењена финансирању локалних инфраструктурних пројеката, с тим да није било трговине на секундарном тржишту капитала. ${ }^{40}$ Емитоване обвезнице немају карактеристике зелених обвез-

37 Дужничке хартије од вредности, односно обвезнице могу емитовати само правна лица тј. привредна друштва (акционарско друштво или друштво са ограниченом одговорношћу) и држава. Најчешће их емитује држава, али и региони и јединице локалне самоуправе (градови и општине), те сходно томе разликујемо државне обвезнице и муниципалне обвезнице. Корпоративне обвезнице су обвезнице које су емитовала привредна друштва.

38 Н. Јовановић, 426.

39 Biljana Ilić, Dragica Stojanović, Gordana Đukić, „Green Economy: Mobilization of International Capital for Financing Projects of Renewable Energy Sources“, Green Finance, Vol. 1, Nr. 2/2019, 105.

40 Гордана Бејатовић, Горан Селак, „Задуживање јединица локалне самоуправе на финансијском тржишту - бенефити емитовања муниципалних обвезница“, Право

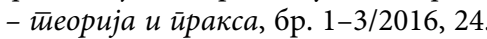


ница будући да средства нису намењена одрживом зеленом развоју. Имајући у виду да је емисија муниципалних обвезница изазвала велико интересовање инвеститора, у перспективи би требало размишљати о емисији зелених муниципалних обвезница с обзиром на значај који би имала прикупљена средства за локалну заједницу. Додатна погодност за инвеститоре у зелене обвезнице су пореске олакшице с обзиром на то да се не плаћа порез на приходе од капитала на камату по основу дужничких хартија од вредности. ${ }^{41}$ У теорији се наводе и друге предности инвестирања у зелене муниципалне обвезнице, попут више каматне стопе у односу на каматне стопе државних обвезница или каматне стопе на депозитне улоге у банци, предвидив ток исплате камате, транспарентност емисије и могућност осигурања. С друге стране, муниципалне обвезнице су повољне и за емитенте из више разлога: задуживање по нижој каматној стопи у односу на алтернативне видове задуживања (нпр. банкарски кредити), привлачење ширег круга потенцијалних инвеститора и могућност превременог откупа обвезница. ${ }^{42}$ Како би се привукли инвеститори да улажу у зелене муниципалне обвезнице, потребно је радити на подизању кредибилитета локалних самоуправа. Оцена кредитног рејтинга емитента (јединице локалне самоуправе) једна је од посредно значајних мера успешне емисије муниципалних обвезница. ${ }^{43}$ Финансирање активности и пројеката за очување животне средине и обновљиве изворе енергије могуће је спровести само у развијеним локалним самоуправама, будући да је низак ризик у случају неиспуњења обавезе од стране емитента, односно јединице локалне самоуправе. ${ }^{44}$

Имајући у виду неразвијеност тржишта капитала, непостојање професионалног кадра, сложеност процедура и постојећи законски оквир, препоручује се ангажовање финансијског саветника као стручног лица у поступку емисије зелених обвезница. С обзиром на недовољне финансијске капацитете локалних самоуправа, од суштинског значаја је проактивно деловање Владе у циљу обезбеђивања већих средстава Комисији за хартије од вредности, Централном регистру хартија

41 Александар С. Мојашевић, Љубица Николић, „Тржиште обвезница јавног сектора у Србији: стање и перспективе развоја“, Зборник раgова Правноі факулиетейа у Huшу, бр. 71/2015, 229.

42 А. С. Мојашевић, Љ. Николић, 230.

43 Поступак емитовања зелених муниципалних обвезница је управноправни поступак који подразумева достављање свих релевантних финансијских података у вези са емитентом обвезница садржаних у проспекту емисије обвезница. Искуства развијених тржишта зелених муниципалних обвезница у свету указала су на то да транспарентност емисије ових обвезница значајно утиче на побољшање кредитног рејтинга емитента. Г. Бејатовић, Г. Селак, 29-31.

44 Д. Стојановић, Г. Ђукић, 332. 
од вредности и Београдској берзи за реализацију зелених пројеката финансијским инструментима. У том контексту, потребно је спровести измене постојећих законских прописа и стратешких докумената. Даље, слабије развијеним локалним самоуправама потребно је пружити већу финансијску подршку од стране Зеленог фонда како би се створили услови за емисију зелених муниципалних обвезница и развијање тржишта капитала. Додатна сметња емисији зелених обвезница у локалним самоуправама јесте непостојање дигиталне и информационе подршке за интернет комуникацију и пословање са инвеститорима путем web портала. 45

\section{V Закључак}

У свету се уочава позитиван тренд раста зелених обвезница од њихове прве емисије 2007. године до данас будући да се тржиште зелених обвезница све више диверсификује са учешћем нових емитената и новим географским подручјима. Међутим, посматрано у односу на тржиште традиционалних обвезница, тржиште зелених обвезница је и даље мало, односно недовољно развијено. Иако су емисије зелених хартија од вредности у претходном периоду расле експоненцијално брзо, како по обиму, тако и по вредности, њихово учешће на светском тржишту капитала је и даље занемарљиво. Емисије зелених обвезница од стране држава, региона и општина (муниципалне обвезнице) требало би да допринесу убрзаном расту тржишта с обзиром на то да оне не представљају додатни ризик за инвеститоре. Додатни мотив инвестирања у зелене обвезнице је виша каматна стопа у односу на каматне стопе државних обвезница или каматне стопе на депозитне улоге у банци, чиме се настоји обезбедити инвеститорима већа профитабилност, ликвидност и стабилност.

Као што смо у раду истакли, не постоје јединствена правила којима се регулише тржиште зелених хартија од вредности. Како би се омогућио даљи развој тржишта зелених хартија од вредности, односно повезивање регионалног и глобалног тржишта, неопходно је усвајање међународних прописа у циљу хармонизације правила којима се регулише ово тржиште.

С обзиром на то да је Република Србија отпочела приступне преговоре са ЕУ, једно од поглавља односи се на заштиту животне средине (поглавље 27) и трансформацију економије и финансијског сектора. Ово је прилика да креатори јавних политика и појединачне финансијске институције примене концепт зелених финансија у остваривању циљева

45 Ibid. 
одрживог економског развоја. Надамо се да ће примере појединих локалних самоуправа које су у претходном периоду емитовале муниципалне обвезнице следити и друге локалне самоуправе у Србији, пре свега емисијом зелених муниципалних обвезница, препознајући све предности овог облика финансирања. На тај начин, допринело би се развоју домаћег тржишта дужничких хартија од вредности на којем би поред државних обвезница, које су тренутно доминантне, у већој мери биле заступљене и зелене обвезнице.

\section{Коришћена литература}

Бејатовић Гордана, Селак Горан, „Задуживање јединица локалне самоуправе на финансијском тржишту - бенефити емитовања муниципалних обвезница“, Право - йеорија и йракса, бр. 1-3/2016.

Wang Yao, Zhi Qiang, „The Role of Green Finance in Environmental Protection: Two Aspects of Market Mechanism and Policies“, Energy Procedia, Nr. 104/2016.

Vella Heidi, „Global Green Bond Partnership: reinvigorating energy investment", доступно на адреси: http://www.power-technology.com/features/ global-green-bond-partnership/, 3. 4. 2020.

Ilić Biljana, Stojanović Dragica, Đukić Gordana, „Green Economy: Mobilization of International Capital for Financing Projects of Renewable Energy Sources", Green Finance, Vol. 1, Nr. 2/2019.

Јанчетовић Мила, Јовановић Радица, Цвијић Јана, „Стратегија комуникације банака и осигуравајућих компанија за одрживи развој“, Mоћ комуникације 2012 (ур. Зорка Грандов, Марко Лакета, Санел Јакуповић), Паневропски универзитет Апеирон у Бањој Луци, Бања Лука, 2012.

Јовановић Небојша, Берзанско ирраво, Правни факултет Универзитета у Београду, Београд, 2009.

Козаревић Емира, Мујић Харис, „Финансирање катастрофалних ризика САТ обвезницама“, Банке и бизнис, јул/август 2019.

Мојашевић Александар С., Николић Љубица, „Тржиште обвезница јавног сектора у Србији: стање и перспективе развоја“, Зборник раяова Правноі факулиетей у Ниму, бр. 71/2015.

Noh Hee Jin, Financial Strategy to Accelerate Green Growth, ADBI Working Paper Series, Nr. 866/2018, доступно на адреси: $h t t p s: / / w w w . a d b . o r g /$ sites/default/files/publication/452656/adbi-wp866.pdf, 5. 4. 2020.

Његомир Владимир, „Улога тржишта капитала у управљању ризиком осигурања“, Иняустирија, бр. 4/2008. 
Његомир Владимир, „Управљање ризиком у осигурању емисијом обвезница за катастрофалне штете“, Економска мисао, бр. 3-4/2006.

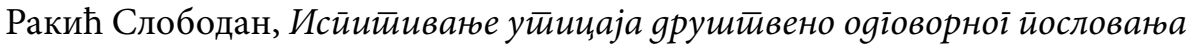

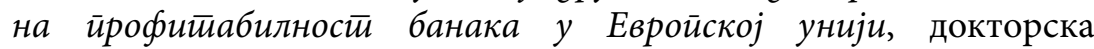
дисертација, Факултет пословне економије Универзитета Едуконс у Сремској Каменици, Сремска Каменица, 2016.

Ракић Слободан, Митић Петар, Green Banking - Green Financial Products with Special Emphasis on Retail Banking Products, Vydavatel'stvo Prešovskej University, Presov, 2012.

Ракић Слободан, Митић Петар, Распоповић Неда, „Примена концепта „зеленог“ у финансијама и банкарству“, Пословна економија, бр. $1 / 2012$.

Ross Alex, Green Bonds: Securities Regulation Towards a Low-carbon Economy, Victoria University of Wellington Faculty of Law, 2018.

Стојановић Драгица, „Зелене финансије - тренд који прати концепт одрживог економског развоја“, 9. Међународни симӣозијум о уйрављағь ирирояним ресурсима (ур. Драган Михајловић, Бојан Ђорђевић), Факултет за менаџмент Мегатренд Универзитета у Зајечару, Београд, 2019.

Стојановић Драгица, Ђукић Гордана, „Зелено финансирање на међународном нивоу - поређење Србије и Сингапура“, 9. Међународни симйозијум о уйрављағу ирировним ресурсима (ур. Драган Михајловић, Бојан Ђорђевић), Факултет за менаџмент Мегатренд Универзитета у Зајечару, Београд, 2019.

Тасић Марија, Правни аспекти издавања и конверзије заменљивих обвезница, доступно на адреси: http://www.tasiclaw.com/fajlovi/ procedura_za_izdavanje_zamenljivih_obveznica.pdf, 10.4. 2020. 


\title{
Ranko SOVILJ, PhD
}

Research Associate at the Institute of Social Sciences in Belgrade

\section{GREEN SECURITIES MARKET - THE SITUATION AND PERSPECTIVES}

\begin{abstract}
Summary
Green finance is an area of finance that is positioned between the financial sector, sustainable economic development and the environment protection. Bearing in mind that this is a relatively new model of financing, the subject of this paper is an analysis of the current situation of green finance, above all, green securities. Using the comparative and normative method, the paper analyzes the market of green securities, especially emphasizing the importance of the green bond market. The paper will outline the current situation and prospects of the development of the green bond market in the national legislation. The conclusion points to the necessity of further development of the green bond market and directing operations of financial institutions towards the creation of new green products and services.
\end{abstract}

Key words: Green Finance. - Securities Market. - Green Securities. - Green Bonds. - Cat Bonds. - Municipal Bonds.

Датум пријема рада: 14. 4. 2020.

Датум прихватања рада: 10. 5. 2020. 